\title{
Utilization of urban sustainability approaches to deal with ancient cities: a case study of Hit Castle, Iraq
}

\author{
Thaer Mahmood ${ }^{1, *}$ \\ ${ }^{1}$ College of Engineering, University of Anbar, Ramadi, Iraq
}

\begin{abstract}
This research aims to highlight the current situation of some Iraqi ancient cities by taking the Hit Castle as a case study. It is one of the oldest cities in Iraq. Due to the previous circumstances that Iraq has one through, this city was ignored and not looked after. Furthermore, due to the expensive land in this city, many old houses were demolished and rebuilt in a modern style. In order to conserve this ancient city, the urban sustainable approaches are suggested to be used. For this purpose, a study was made and a site observation was carried out. Based on that, it was found that this city could be redeveloped/ rehabilitated by employing the urban sustainability approaches and concepts. Important recommendations have been identified and the governmental bodies will be invited to conserve the ancient cities using these recommendations as guidelines.
\end{abstract}

\section{Introduction}

The ancient and historical sites are comprise of noteworthy number of heritage sites and thus it necessitates further efforts for conservation and redevelopment for future generations [19]. Globally and most recently, recognizing urban legacy concerning illustrations, and urban destinations as opposed to single monuments has bee

$\mathrm{n}$ placed ahead by distinctive authorities, like experts, academics, professionals and global associations [12].Redevelopment and rehabilitation can yield significant improvements to the ancient cities. Indeed, they enhance the caliber of the built environment, encourage the appreciation of the city's history and culture, and support the character and community's personality [14] .Several factors influence the motivation of using the redevelopment and rehabilitation for the ancient cities including population increase, the failure of existing building stock, economic activities and the demand for higher level of living $[3,5,7,11]$.

Sustainability development resides at the nexus of philosophy, practice, politics, and engineering organization [6]. The main concept of sustainability development in cities is harmonized between three elements, namely society, environment and economy $[10,17]$. Based on these three elements, a reliable and cohesive foundation, and conditions for sustainable cities can be yielded $[13,18]$ as reported in their research that cities sustainability development is maintained through the integration between social progress, environmental support and economic development. In another study, it was stated that maintainable advancement to urban communities includes economical progressions of population, maintainable advancement of assets, ecological markets, and economic progress of urban governance [13]. These transformations and the unpredictable

Biological framework of the urban environment, society, and economy end up in adjustments and facilitated a sensible structure, optimized organization, furthermore exceedingly successful operation $[8,15]$. In the literature, cities sustainability developments were inspected by several scholars that reflect the sustainability of urban systems $[1,2,4]$.

The planning was compatible with the peoples' mentality in the far time. Their view was simple and they were satisfied with their situation in terms of their houses and environment regardless of whether it was right or not. The urban and technical evolution had directed the humans thinking to restudy and re-plan their lives to be fitted with this development in terms of the future expansions and considering the environmental circumstances in the design of their cities [6]. In order to plan the ancient cities to be exist, historical studies should be carried out for the buildings and residents. These cities should be conserved and recovered within the general frame of the new cities and they should be treated as a live body that interacts with the different residents activities. When an ancient city is to be replanted, the following considerations should be taken into account:

Stop the deterioration and disappearance of the ancient city by repairing and maintaining the existing buildings.

\footnotetext{
Corresponding author:drthaersh@gmail.com
} 
Organize the land use by defining each use in a beneficial manner by determining the population density, the building height, and legislative laws that aid in conserving the buildings in the ancient cities.

Reroute the vehicle traffic outside the ancient cities and restrict the car traffic for only necessary uses.

Increase the urban awareness for these city residents about the importance of these unique environments.

The recognition of the ancient buildings as a heritage value that should be conserve them has started in some European countries early the last century particularly after the world wars [4]. This recognition represents by renew and development of the ancient cities as they represent the history and civilization of any country. Later on during the second half of the last century, the developing countries have stated to be interested in renewing the ancient cities that they have. The studies that have been conducted in this regard have established some theoretical fundamentals meanwhile different methods for conserving the ancient cities have been concluded. Iraq is considered to be one of the richest countries all over the world in its heritage and legacy where it can be seen that there are numerous ancient cities that need to be rehabilitated and conserved.

The presented study aims to establish a reliable planning approach including redevelopment/rehabilitation of an ancient city that is older than Babylon city. The ancient Hit city (Hit Castle) is located in Anbar province, Iraq. The significance of this case study "Hit Castle" is owing to its outstanding coordinate which lies on the Euphrates River. In addition, this castle was initiated within the same period of the ancient cities of the Mesopotamia region. Hence, applying the proposed approach is highly recommended for the same heritage monuments that initiated within the same period. The study focuses on the understanding the reality of the situation in Hit Castle and find out the possibility of applying the suitable policy of urban sustainability. The implementation approach for the urban sustainability and the planning indicators are related to the land use and the role of the construction materials used to identify some applicable recommendations to prevent the heritage locations from deterioration and urban and ecological collapse.

\section{Urban sustainable plan for hit castle}

When developing an urban renewal plan for an old traditional Arab city, it is necessary to preserve the implicit standards of the city that guided the planning of this city and gave it this distinctive form. These criteria depend not only on the social, economic and environmental factors, but also on the religious factors in the city since its inception. The mosque in the city (Al Farouk Mosque) is located on the side overlooking the river and not in the center of the city because the city is very old and was Jewish in the past as confirmed by most historical books as shown in the schematic.

The tabulated theoretical concepts abstracted from the state-of-the-art relevant researches [19]. In this research, the spatial analysis approach has been used to study the status of Hit Castle that represents a historical heritage city located in the Mesopotamia region. The spatial analysis approach was used owing to the following reasons:

Nowadays, a noticeable shrinkage of the urban area.

An increasing and expanding in the urban state destruction all over the study area.

Land is buzzing and misapply.

The importance of conserving the historical symbols areas that present a cultural heritage monument.

The necessity of achieving the sustainability of such urban heritage cites.

Facts and data collection were obtained from the original Civil and Department of Municipality of Hit City, and by interviewing the researchers of previous studies $[9,14]$ Additionally, facts and data were collected based on inputs from the former residents of the study area in order to reach the proposed policies for sustainability of urban area of Hit Castle. The data were analyzed using interviews, participating style with allocative groups depending on the superiority of the stakeholders to consider the proposed redevelopment and rehabilitation of an urban sustainable development policy.

A number of scientific conferences have stressed the high desire of the population to renew their ancient cities and to preserve the cultural heritage and the urban cohesive fabric that was ingrained in the traditional Arab cities where civilization and heritage cannot be purchased, but need preservation and sustainability of the heritage remain in the cities. The development of the plan for urban renewal includes several dimensions:

2.1 Desires of the inhabitants of the city

The most important things taken by the plan of urban renewal in the development of its scientific and technical plan is to take into consideration the wishes of the population in the work of urban sustainability and maintain a unified tendency to retain the spiritual and social values derived from Islamic teachings and embody these tendencies in the urban form of the city We move away from the cloning of modern and western architecture, The latter deviates from the desires and approaches western laws and regulations that are often destructive to the cultural and historical heritage of the city and are far from the urban sustainability plan carried out in preserving the historical and heritage areas which bear the values and history of peoples and tribes with a history of ancient life. 


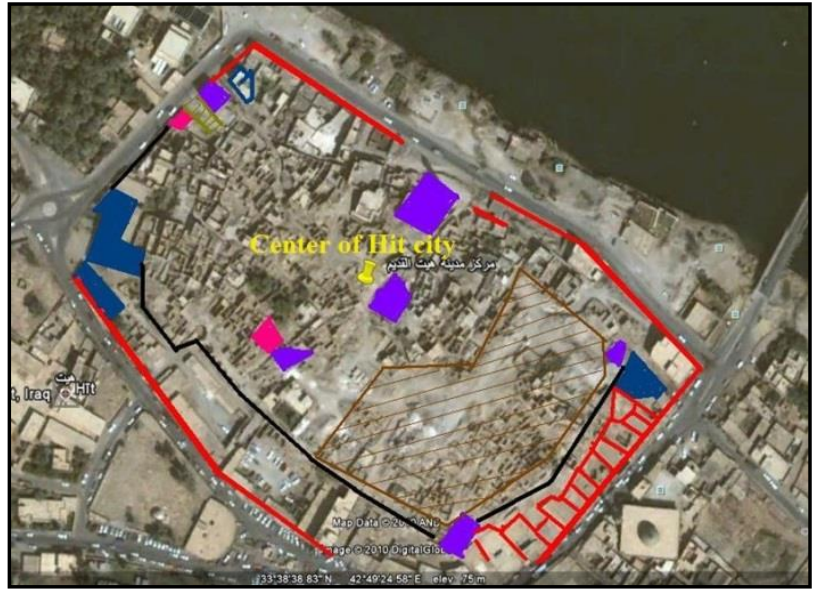

Fig.1. Satellite image for ancient Hit city castle

\subsection{City size}

Urban sustainability requires a limited area. Therefore, when developing an urban renewal plan, a governance must be established for the total population to avoid the urban problems resulting from overcrowding, misuse of urban spaces and distortion of the urban structure of the city, etc. The population increase can be planned within the extensions of the municipality of Hit in the east and west of the city, which draws and accommodates population growth and new families.

\subsection{Urban structure}

The clear from the foregoing that the market forces play a prominent role in the formation of a new urban structure for the city of Hit similar to the structure of other cities in the capacity of its streets and the disruption of the urban fabric of the old city and its center in Hit, The urban sustainability plan includes an urban structure derived from traditions and orientation to the social aspects supported by the spiritual values of the city. The technological progress and change in the commercial, economic and security movement in the city will be observed. In the center of the old city of Hit there will be regular elements represented by the integrity of the commercial axis of the city and parallel to the river and around the fence.

\section{Strategic plan for urban sustainability}

The aims of the urban sustainability have been previously highlighted. In addition general and planning concepts and indications about the ancient city of Hit in terms of different land uses and the required areas for these uses are specified. In order to make the studied city attractive for the residents, the planning problems and urban features should be sorted out based on the urban sustainability plan by applying the scientific and planning manners for the urban renewal [20] as demonstrated in Table 1. The approaches of urban sustainability to develop and conserve the Hit Castle can be stated by explaining the urban sustainability polices as follow:

\subsection{Urban sustainability polices}

These deal with the urban structure of the Hit ancient city which in turn represents the urban tissue and planning structure (residential regions and its aspects). In fact, ther are many planning indicatores and concepts for the urban sustainability namely:

1. Sustainable urban planning indicator, which represents the ideal distribution for the land use in the city.

2. Sustainable habitation and housing indicator.

3. Sustainable transport indicators.

4. Sustainable commercial use indicator.

5. Sustainable industrial use indicator.

6. Sustainable under and above services indicator.

7. Green zones indicator.

8. Clean energy indicator.

9. Sustainable and renewable energy indicator.

10. Social sustainability indicator.

11. Privacy in dealing with the historical centers indicator.

Table 1. Urban sustainable methods on the Hit castle

\begin{tabular}{|c|c|c|}
\hline Quarter & Redevelopment & Rehabilitation \\
\hline $\begin{array}{l}\text { Western } \\
\text { door } \\
\text { quarter }\end{array}$ & $\begin{array}{l}\text { Develop and improve } \\
\text { some of the } \\
\text { residential, } \\
\text { administrative, and } \\
\text { commercial buildings. } \\
\text { The ancient city s } \\
\text { urban morphology } \\
\text { should be maintained } \\
\text { in addition to the } \\
\text { traditional style of the } \\
\text { buildings such as } \\
\text { buildings orientation, } \\
\text { shadow provision. } \\
\text { Modern buildings can } \\
\text { be constructed outside } \\
\text { the castle and the link } \\
\text { between the old and } \\
\text { the modern building } \\
\text { should be considered } \\
\text { and also the } \\
\text { orientation of } \\
\text { buildings to be } \\
\text { compatible with the } \\
\text { sun and wind } \\
\text { movements. }\end{array}$ & $\begin{array}{l}\text { For a li,ited number of } \\
\text { heritage buildings } \\
\text { rehabilitate the residual } \\
\text { buildings as they have } \\
\text { an architectural value. } \\
\text { These buildings can be } \\
\text { reused for suitable } \\
\text { activities to activate the } \\
\text { social and economic } \\
\text { life in the city center in } \\
\text { addition to cultural role } \\
\text { and tourism } \\
\text { development. In order } \\
\text { to achieve, the } \\
\text { modifications of } \\
\text { traditional urban tissue } \\
\text { should be prohibited } \\
\text { and also all the } \\
\text { deformation should be } \\
\text { removed. In general, } \\
\text { the entire original } \\
\text { designs in terms of } \\
\text { architectural, } \\
\text { pedestrians, and } \\
\text { commercial, etc. } \\
\text { should be maintained } \\
\text { whenever possible. }\end{array}$ \\
\hline
\end{tabular}




\begin{tabular}{|c|c|c|}
\hline $\begin{array}{l}\text { Southern } \\
\text { door } \\
\text { quarter } \\
\text { (Al- } \\
\text { wesata) }\end{array}$ & $\begin{array}{l}\text { Modern buildings } \\
\text { could be constructed } \\
\text { to be similar to the } \\
\text { old ones that face the } \\
\text { river. Same building } \\
\text { materials for the } \\
\text { original ones should } \\
\text { be used in addition to } \\
\text { utilizing modern } \\
\text { technologies in terms } \\
\text { of making the front } \\
\text { views for the new } \\
\text { buildings to be } \\
\text { compatible with the } \\
\text { old ones to conserve } \\
\text { the historical flavor. } \\
\text { The land use should } \\
\text { be made to construct } \\
\text { multi-story car parks } \\
\text { and provide enough } \\
\text { spaces to be used for } \\
\text { walking and having } \\
\text { joy. }\end{array}$ & $\begin{array}{l}\text { Rehabilitate the regions } \\
\text { that were destroyed due } \\
\text { to the last war which } \\
\text { have a historical value } \\
\text { in addition to repairing } \\
\text { the city infrastructures. } \\
\text { When new buildings } \\
\text { are constructed they } \\
\text { have to have the same } \\
\text { height to conserve the } \\
\text { street styles and the } \\
\text { pedestrians' paths. The } \\
\text { new rehabilitated } \\
\text { building should } \\
\text { maintain the } \\
\text { compatibility between } \\
\text { the new and old } \\
\text { buildings. }\end{array}$ \\
\hline $\begin{array}{l}\text { Eastern } \\
\text { door } \\
\text { quarter }\end{array}$ & $\begin{array}{l}\text { Construct new } \\
\text { buildings while } \\
\text { conserving the urban } \\
\text { morphology for the } \\
\text { traditional city and } \\
\text { residential unites such } \\
\text { as buildings } \\
\text { orientation, shadow } \\
\text { provision and } \\
\text { constructing new } \\
\text { modern buildings } \\
\text { outside the ancient } \\
\text { city taking into } \\
\text { account the buildings } \\
\text { orientation in terms of } \\
\text { sun and wind } \\
\text { direction. }\end{array}$ & $\begin{array}{l}\text { Rehabilitate and repair } \\
\text { the heritage buildings } \\
\text { and adding new uses } \\
\text { for the buildings that } \\
\text { do not have heritage } \\
\text { vale by using them as } \\
\text { car parks and widening } \\
\text { the main street in the } \\
\text { western parts of the } \\
\text { ancient city in addition } \\
\text { to rehabilitate the } \\
\text { infrastructures. An } \\
\text { urban fulfill, by new } \\
\text { building, should be } \\
\text { made for the areas that } \\
\text { surrounding the Sit- } \\
\text { Nafesa Mosque and } \\
\text { these buildings should } \\
\text { be compatible with the } \\
\text { existing buildings. }\end{array}$ \\
\hline
\end{tabular}

\section{Implementation approaches for urban sustainability}

Conservation of urban tissue, and planning and urban structure

This can be achieved by conserving the urban tissue for the ancient city in addition to the urban congestion, at the same time conserving the unique planning structure for the ancient city center as shown in Fig 1 . It can be seen that there are impressive solutions for the weather conditions by designing the residential neighborhood, zigzagged alleys planning, internal and external squares, etc. In order to renew the ancient city in an urban manner, minor modification can be conducted to provide some essential services for the house's owner (residents).

\subsection{Residential use of the Hit castle}

The residential units are counted as irregular elements in the urban structure which includes residential buildings. It is planned that 2665 people (approximately 429 families) to be accommodated in 429 residential units; therefore, the number of residential units must be maintained. Table 2 shows the actual situation nowadays of the residential units.

Table 2. The urban case analysis for the residential buildings in Hit castle

\begin{tabular}{|c|c|c|}
\hline $\begin{array}{c}\text { The residential unite } \\
\text { situation }\end{array}$ & Number & Percentage \\
\hline Engaged & 78 & $18 \%$ \\
\hline Demolished & 296 & $69 \%$ \\
\hline $\begin{array}{c}\text { Needed for } \\
\text { rehabilitation }\end{array}$ & 34 & $8 \%$ \\
\hline New & 21 & $5 \%$ \\
\hline Total & 429 & $100 \%$ \\
\hline
\end{tabular}

From Table 3, it can be noted that 330 residential units need repairing, rehabilitating and modification. There are 99 residential units could be expected from the rehabilitation works as they need just minor maintenance that includes new unites as presented in Table 2; however, these could be removed and redesigned to be compatible to the existing original ones. In general, each unite could be historically and urbanely studied and then a decision can be made whether it can be repaired or not. In fact, there are some unites almost destroyed; therefore, there is no economic feasibility in terms of repairing them. However, these unites could be utilized by redeveloping them urbanely but the compatibility of urban tissue and structure should be carefully considered.

Table 3. The urban situation for the residential units and the urban sustainable methods for treatment

\begin{tabular}{|l|l|l|}
\hline $\begin{array}{l}\text { Urban } \\
\text { situation }\end{array}$ & Renewal policy & Future function \\
\hline Engaged & $\begin{array}{l}\text { Urban } \\
\text { conservation }\end{array}$ & Residential use \\
\hline Demolished & $\begin{array}{l}\text { Redevelop and } \\
\text { conserve }\end{array}$ & $\begin{array}{l}\text { Residential use } \\
\text { and services }\end{array}$ \\
\hline $\begin{array}{l}\text { Needed for } \\
\text { rehabilitation }\end{array}$ & Rehabilitation & Residential use \\
\hline New & $\begin{array}{l}\text { Conserve and } \\
\text { rehabilitation }\end{array}$ & Residential use \\
\hline
\end{tabular}

\section{2 Commercial services}

It is one of the regular elements of the urban structure that lay along the ring street that surround the ancient city as illustrated in the schematic diagram (Fig.2). These streets are mostly modern due to being open. These streets tear the urban tissue, especially in the direction of the river. Thanks to the improvement in living standards and time factor, these streets are given strange character in terms of the capacity of streets and building shapes and height, which are three and four 
floors for some buildings while in the ancient city it did not exceed one floor for commercial use and no more 15 $-32 \mathrm{~m} 2$.

The plan for urban renewal contains rebuilding the destroyed urban tissue in the direction of the river and modern markets. This should be combined with providing wide sidewalks for the pedestrians, specific lanes for emergency service vehicles like ambulance, fire, etc. without being used by the residential and visitors' cars. Additionally, the essential services such as water, sewage, lightening, and communications should be served using separated paths in order to provide good services for the residents.

In these areas, excesses have occurred with increasing the height of buildings to three floors, especially, in the street that overlooks the river and the modern market. The other excess is the change in land use from residential to commercial because of the increased price of land in the region. It can be noted that most of the new buildings are reinforced concrete structures and the others were built using concrete blocks whereas the old construction were built using the clay brick and the roofs were built using wood and mud as it will be explained later. The architectural deformation is clearly seen in this area and strict regulation should be legislated to conserve the traditions and values of this city. The main reasons for stopping construction of multistory concrete commercial buildings in this area can be summarized as follows:

1. The street's traffic jams due to multi use buildings.

2. The change in the commercial use from small shops to large store because of the large space

3. The structural construction is considered as strange style and this is easily noted at the first-time it has been seen due to the difference between the old and the new buildings.

4. The multistory buildings caused prejudice in the balance of the old city and damage historical and cultural appearance

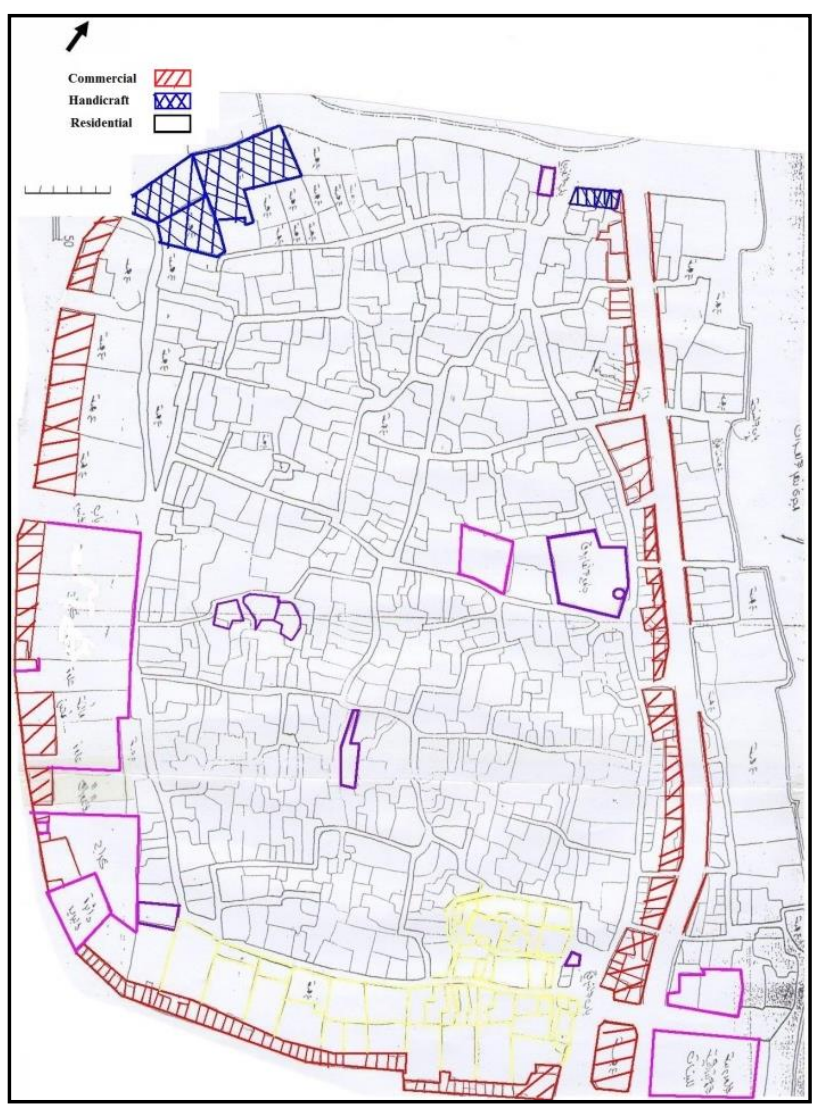

Fig.2. Schematic diagram for the urban sustainability for the commercial, handicraft and residential uses in Hit City Castle.

\subsection{The infrastructure services (above and underground)}

From the site visits to the Hit Castle, no services have been seen where there was either sewage or rain discharge network. The electricity services are not sufficient in general. Regarding the drinking water network, a new one has been constructed by the United Nation program, whereas there is no communication services at all. In order to improve the provided services for the residents, the following points should be considered:

Improve the drinking water in the residential, commercial, and social services buildings.

5. Develop a new mechanism for disposal of the solid waste outside the city by providing small cars and small closed vehicles.

6. Construct sewage network for the residential, commercial, and public service buildings.

7. Construct a rain, discharge network or instead provide a surface network if the first is difficult to be constructed.

8. Improve and repair the existing electricity network based on a standard level and utilize the sun power in lightening and generating electricity.

9. Provide a communication network (wire and wireless) based on the available technologies. 
10. Improve the roads efficiency for both paved and unpaved streets. The unpaved roads, can be paved using the locally-available materials (tar and aggregate). This can be done via the support of the Hit City mayoralty.

\subsection{The traffic and transportation services}

The uses of traffic and transportation in the ancient city contain some limitations that should be included, by the planner, in the renewable plan. The car traffic through the ancient city should be prevented and the passage of cars should be limited to the ring road as shown in Fig 3, where the traffic should be limited to the three entrances as suggested in the urban sustainable plan and the ring and commercial road. There is an increase in the pedestrian paths which are grouped and interrelated to be reached to the city ring road. The vehicles can enter from the Eastern door to reaches to the small mosque (Sit-Nafesa) and from the Western door to Al-Khareef door. A hierarchy in the pedestrians' roads could be conducted till the project road, while the commercial road the parallel to the river can be used to passed the vehicles through the modern market.

The suggested entrance by the researchers is located near to the Hag Omer Hindi garage, where the vehicles can enter till the wall entrance and then only pedestrians can pass due to the narrow paths. Suggested car parks for the car owners who live in the ancient Hit City in addition to the visitors and shoppers can be located near to the Eastern entrance towards Hit bridge and Hag Omer Hindi could be developed to be multi-story car parks. In order to widen the street, the private lands can be bought by the Hit City municipality from the owners.

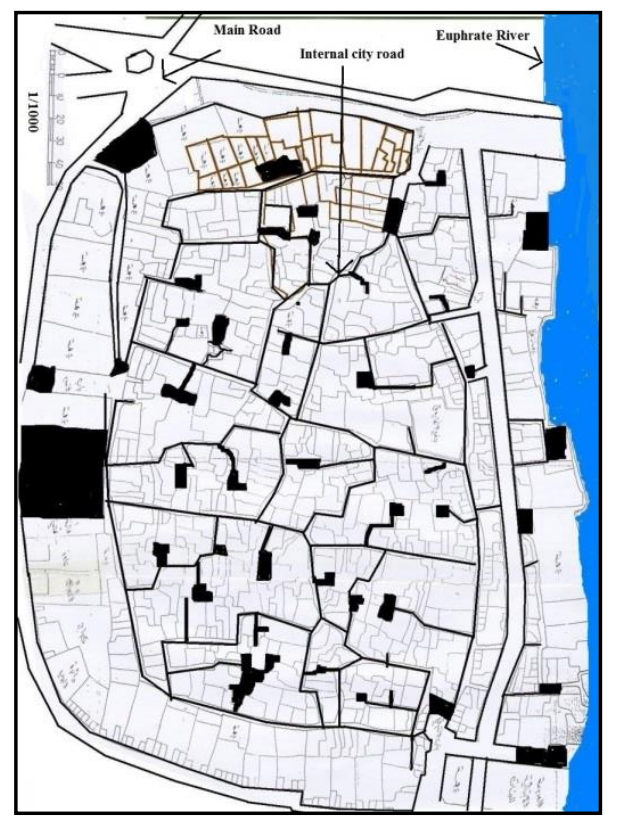

Fig.3. Schematic diagram for the urban sustainability for the pedestrians, traffic, and transport

\subsection{Materials roles in urban sustainability}

The used construction materials in Iraqi ancient civilizations such as Mesopotamia, Nineveh, and Sumerian were mainly clay-based materials. This was due to the nature of the geological formation that led to use this material for more than 5000 years ago. The ancient Iraqi cities, especially in the middle and south of Iraq were built on sedimentary lands which made use of clay due to its availability, ease in-manufacturing and building such as Babylon and Orr. The clay (mud) was formed into building units by mixing the clay-soil with water and adding straws from locally-available plants as reinforcement to produce clay brick. These units are known nowadays as brick; however, the main difference is the modern brick is burnt whereas the old units are air/sun dried. As it has been previously mentioned that Hit is one of the oldest Iraqi cities, however, clay brick was not used in building the houses.

A sophisticated technique was developed in ancient Hit City which characterized by using small stones that were bound together using the lime as a binder as shown in Fig. 4. This technique is considered a significant step towards the durable construction as use of the brick neededs to be maintained almost yearly. Whereas, the stone and lime are durable construction materials, therefore, using them to save time and resources. The wall's width was about $50 \mathrm{~cm}$ while the foundation is about $1 \mathrm{~m}$. The gypsum was used for plastering the inside wall and the lime with sand for outside use.

The roofs were constructed using wood beams in the short direction and some plans residual were used in the other direction to make a covering for the roof with mud and tar as seen in Fig 4. Interestingly, some of the roofs were built using the arches rather than flat roof which means that even at that time there was a fundamental understanding of the 'modern' structural theories. The use of locally-available materials (stone and lime) and the width of the walls in addition to the inside and outside layers of gypsum and lime could provide a unique thermo-physical behavior and thermal insulation for the building (house).

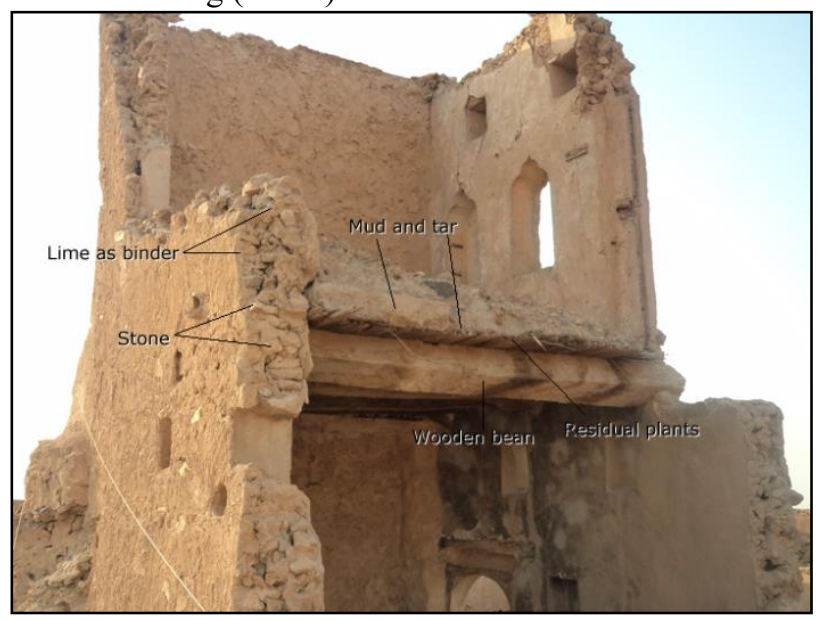

Fig.4. Walls and Roofing system in Hit Castle's houses 


\subsection{Rehabilitation of the damaged houses}

In order to conserve the historical/heritage value of the Hit Castle and to achieve the sustainability aim, same locally-available materials can be used i.e. reused the same (demolished) materials. Even if there is a shortage in some materials, natural resources (stone, lime, wood, tar) should be used which is widely available in the studied city. The architectural/ structural style should be conserved by using the same material; however, the newly-developed building materials can be used in order to make the repaired houses sustainable and (durable).

\section{Conclusions}

Based on the study conducted and the detailed analysis of the surveyed information, the following conclusions can be highlighted:

The Hit Castle has a historical value where it was a Jewish city before the Islamic distribution; therefore, it can be counted as a heritage city that should be conserved from the accelerated urban deterioration.

$>\quad$ The increase in demolition works for older houses and rebuilding of these houses using modern materials and style increases the architectural style (urban pollution) and gives a negative impression from the urban and architectural legacy.

$>\quad$ The variety in the land use in Hit Castle provides indicators for using different urban sustainability approaches in addition to applying a group of policies that related to each type based on its structural situation.

The unique location for a Hit Castle beside the Euphrates River has given it an important architectural indicator that needs to be compatible with the modern construction. Where, it has been noted that modern commercial buildings has taken an important part of the urban structure of the ancient castle.

$>\quad$ The already-existing demolished construction materials can be reused in rehabilitating the residential/ commercial buildings in order to keep the historical value in terms of the materials and styles.

$>\quad$ For foundations and roofing works, locallyavailable materials such as lime, stone, wood, tar, clay, and residual plants can still be used; therefore, the maintenance and rehabilitation works will be easily implemented. In some situations, the developed construction materials can also be used by keeping the general style compatible with the original buildings.

In order to bring the attention to the ancient cities that cannot be found everywhere and to highlight the importance of using the urban sustainability approaches, the following recommendations can be emphasized:

$>\quad$ Conduct a comprehensive study (planning and historical) to determine the historical value of the buildings in the Hit Castle.
Implement the planning instructions and laws that deal with conserving the buildings having heritage value and stopp the demolishing and urban change works.

$>$ Limiting the construction of multi-story commercial buildings on and near to the castle in order to minimize the urban pollution.

$>$ Conserve the variety of land uses in the Hit Castle and attempting to simulate this variety in other locations in the city after employing the most modern technology.

\section{References}

1. J . Breuste, S. Qureshi, Urb. Eco. Sys. J. E 14, 3(2011)

2. S. Cambell, Readings in Planning Theory (John Wiley \& Sons, 2016)

3. F. Cheng, S. Geertman,et al., Env .\& Urb .Sys. J. E $35,5(2011)$

4. D.L. Childers, M.L.Cadenasso, et al.,Sust. J. E 7,4 (2015)

5. J.P. Ganning, Eco. Dev. Quar. J. E 30, 3 (2016)

6. J.D .Gatrell, R .R. Jensen,et al. Sustainability: Policy and Praxis (McGraw -Hill, 2016)

7. A. Gospodini, Cities, J. E 18, 5 (2001)

8. T. Hak, J. Kovanda,J.Weinzettel,Eco.Ind. J. E 17,1(2012)

9. A.M. Hassan, Damascus Eng. J. E 2,12(2012)

10. Y.R. Jabareen, Planning Edu. \&Res. J. E 26,1 (2006)

11. T. Kuyucu,D. Danis, Urb. Aff. Rev. 51,3(2015)

12. P. Pattananurot, Procedia Eng. J. E 32,(2012)

13. R.R. Shaker, I.G. Sirodoev, Habitat Int. 55, 2 (2016)

14. F.Steinberg, Habitat Int. 20,3 (1996)

15. L. Tran, Ecological Indicators, 61,1(2016)

16. H. Wang, Transp. Geog. J. E 40, 2 (2014)

17. N.H. Wong, S.K. Jusuf, C.L.Tan, Land.\& Urb. Plan. J. E 100,4(2011)

18. J. Zhang, ACTA Geog. of Chin. J. E 56,1 (2001)

19. B. Yang, L. Shi, Cleaner Production, J. E 141(2017)

20. A. M. Hassan, Dmascus Eng. J. E 2,13(2012) 